\title{
Producers' Perception of Collective Action Initiatives in the Production and Marketing of Kola in Cameroon
}

\author{
Amos Gyau \& Bertin Takoutsing \\ World Agroforestry Centre (ICRAF), West and Central Africa Region, Yaoundé, Cameroon \\ Tel: 237-22-215-084Ｅ-mail: a.gyau@cgiar.org
}

Steven Franzel

World Agroforestry Centre (ICRAF), Head quarters, Nairobi, Kenya

$\begin{array}{lc}\text { Received: October 31, } 2011 & \text { Accepted: November 14, } 2011 \quad \text { Online Published: February 2, } 2012 \\ \text { doi:10.5539/jas.v4n4p117 } & \text { URL: http://dx.doi.org/10.5539/jas.v4n4p117 }\end{array}$

\begin{abstract}
Collective action has been promoted as a strategy to improve the incomes of small scale producers in many developing countries, primarily by reducing transaction costs and improving farmers' bargaining power. This paper evaluates producers' perception of collective action initiatives which have been used in Cameroon for the production and marketing of kola nuts. Using a perceptual evaluation and cluster analysis based on interviews with 203 kola producers in western highlands of Cameroon, findings reveal that producers evaluate effectiveness of collective action based on 5 main groups of criteria: reduced transaction costs, new learning and skills acquisition, market and financial status, social networks and status, and unfavorable dimensions. Furthermore, two main types of producers who evaluate the collective initiatives differently are identified: the positive group and the unimpressed group. Higher proportions of women and youth are in the unimpressed group than in the positive group, suggesting that more needs to be done to understand their perspectives and better target collective action initiatives to their needs and circumstances. The paper concludes that promoters of collective action initiatives need to adopt differentiated strategies to enhance its adoption in the study area.
\end{abstract}

Keywords: Collective action, Kola, Farmers' perception, Cameroon

\section{Introduction}

Development practitioners are becoming increasingly concerned about improving smallholder farmers' market access. This is against the background that market access is seen as one of the important instruments which can be used to improve income and employment (Doward et al, 2003), and subsequently alleviate rural poverty. This notwithstanding, smallholder farmers are often at a disadvantage compared to large scale producers who have technology, capital, information and capacity to produce larger volumes which increases their bargaining power (Devaux et al., 2009). Smallholder farmers' limited access to physical and financial resources restricts their ability to expand and invest in efficiency enhancing technologies. They often have limited technical skills and consequently have high transaction, assembly and transportation costs per unit compared to larger scale producers (Devaux et al., 2009). There is increasing evidence from both research and practice that smallholders can overcome market imperfections and effectively participate in markets by organizing into farmer groups or producer organizations (Shepherd, 2007, Barham \& Chitemi, 2009). The farmer groups as a form of collective action can help smallholders to reduce barriers to the entry into markets by not only lowering the transactions costs for their market exchanges, but also by improving their bargaining power. Furthermore, collective action in the form of farmer groups can also promote linkages across the market chain and connect producers, processors, and buyers into networks that would be beneficial for all actors (Kariuki \& Place, 2005).

In Cameroon, collective action in the form of farmer organizations has been used as a strategy to increase the benefits of agriculture and forestry to smallholder farmers. This is particularly against the background that producer organizations have been widely heralded as leading contributors to poverty alleviation and food security by many development organizations (FAO, 2010). After many years of facilitating collective action initiatives in the kola supply chain in Cameroon, there is a need to assess farmers' perception of the effectiveness and usefulness of such initiatives. This is expected to provide information for organizations using collective 
action to be able to examine their own activities and determine whether they are effective in improving smallholder farmers' livelihoods. In view of this, this article examines kola producers' perception of collective action initiatives in the western highlands of Cameroon with the aim of providing information that would be used to integrate farmers' concerns into the implementation of collective action activities. A combination of qualitative and quantitative research methodologies were used to identify the main criteria for evaluation of collective action and subsequently, farmers' evaluation on these factors was elicited.

The remaining sections are organized as follows: First, we provide background about collective action involving kola in the study area. Second, we identify the main factors which farmers take into consideration in evaluating collective action activities. Third, farmers' perception based on the identified factors is evaluated and they were then segmented based on their perception scores. Results and discussions are presented next. The final section provides conclusions and implications for future implementation of collective action activities.

\section{Literature Review}

\subsection{Defining Collective Action}

Collective action is an action taken by a group either directly or indirectly in pursuit of members' perceived shared interest. Vermillion (2001) defines collective action as a coordinated behavior of a group towards a common interest. Kruijssen \& Giuilianin (2007) argued that initiation of the process of social learning and collective action is caused by a trigger which can be found in many external factors which are usually beyond the control of the individual small holder. This may range from natural disasters to price declines and increased competition. They argued that for collective action to be successful and useful there should be a constraint to carrying out the activity individually and there should be a willingness to undertake the activity as a group demonstrated by a certain level of interconnectedness, motivation and capacity.

In synthesizing the works of Wade (1988), Ostrom (1990, 1992), and Baland \& Platteau (1996), Agrawal (2001) developed a list of conditions for enabling successful collective action. The conditions include: small group size, clearly defined boundaries, shared norms, past successful experience, appropriate leadership, interdependence among group members, and heterogeneity of endowment, homogeneity of identities and interest, and low level of poverty. Collective action that promotes empowerment of small farmers will help them to overcome specific barriers to becoming part of the market economy (Humphrey, 2005).

\subsection{Research Context}

Kola nuts are an important product throughout West Africa and serve many purposes. They are mainly an important stimulant and medicine and are sold to generate income especially for the rural poor (Facheux et al., 2011). Despite their importance, the market chain is not well developed, mainly as a result of poor harvest and postharvest handling of the product leading to high levels of post harvest losses. These bottlenecks challenge the small holder farmers to efficiently engage in the production and the marketing because they restrict their abilities to increase their scale of production. Increasing production could in turn reduce transaction costs and promote investment in efficiency-increasing strategies. To address the challenges, many development and research organizations have used collective action initiatives, particularly the promotion of producer organizations, as a strategy to improve farmers' participation in the chain. These producer organizations carry out certain activities with the aim of improving the supply chain in order to make it more effective. These activities include organizing members to produce improved seedlings to regenerate old and unproductive trees on farms and producing or collecting kola nuts and marketing them. Marketing here also involves facilitating links between producers and buyers, and identifying and establishing business relationships with potential buyers. In addition, several other activities are undertaken collectively around bulking, sorting, storage and quality grading.

Although collective action activities have been carried out for many years for kola, farmers' perceptions about the initiatives are still not very clear. This is important in order to determine the main bottlenecks associated with collective action so as to address them.

\section{Methodology}

\subsection{Description of the Study Area}

The study was carried out in the West and North West regions of Cameroon. The two regions have an area of 31,400 sq. $\mathrm{km}$ and a population of about 3,449,000 estimated in 2005. Together these regions make up the "Western Highlands" of Cameroon owing to the similarities in physical, human, economic and cultural geographies (Neba, 1999). The western highlands are composed of hills and valleys with the highest peak being at mount $\mathrm{Oku}$ at $3011 \mathrm{~m}$ and low areas dipping as low as $500 \mathrm{~m}$. Plateau areas range between $1500 \mathrm{~m}$ and $2200 \mathrm{~m}$. Most of the remaining terrain is covered by large hills and deep valleys. Farm sizes are generally small and some 
farmers grow kola trees in their farms. The main non-timber forest products which are produced or exploited from the wild apart from kola include bush mango (irvingia gabonensis) and safou (Dacryodis edulis). All of these products are widely used in local markets, national markets and across national borders.

\subsection{Data Collection Procedure}

The study took place in March and April 2011 using a multi-step sampling procedure. First, the agro-ecological zones of the two regions (West and North West regions of Cameroon) were identified taking into consideration two important parameters; the production volume and market potential of kola. This enabled stratification of the study area into high and low production and market potential areas. Six different zones were obtained namely: Ndu, Tatum, Batibo, Mbengwi, Bayangam and Bangangte.

The second level of sampling involved choosing the villages and localities for data collection which were distributed across the production zones determined at regional level. The level of organization of the producers and their implementation of collective action initiatives were also considered in the choice of villages within these zones. This was to ensure that both low and high production zones, and key kola nut production and market centers were covered during the study.

In the next step, two focus group interviews with actors along the kola chain were conducted. The aim of the focus group interviews was to identify the main factors which kola producers use in evaluating intervention activities with particular emphasis on collective action initiatives. The focus group interviews also discussed some issues including farmers' motivation and behavioral intentions about collective action. Based on the focus group results, five main factors were identified and considered to be relevant. In the next stage, these factors were validated based on discussions with experts who have worked in collective action as well as other experienced and knowledgeable producers.

Next, a questionnaire was designed based on the factors identified above and the collective action literature. A 5-point Likert scale was used to record responses to questions (ranging from $1=$ strongly disagree to $5=$ strongly agree) and was useful for eliciting farmers perceptions. Before the field survey, the questionnaire was pretested to ensure suitability. Feedback received were used to adjust the questionnaire accordingly.

The next step was to select producers involved in collective action from each of the six zones identified above. Thirty six farmers who have been involved in collective action were randomly selected from each zone using lists provided by community-based organizations. The total sample was thus 216 farmers. The data were collected by six trained enumerators who visited the farmers either on their fields or in their homes depending on convenience. After cleaning the data, 203 questionnaires out of the original 216 were found suitable for analysis.

\subsection{Statistical Analyses}

The empirical analyses were executed in multiple phases. In the first step, descriptive statistics were generated using the SPSS statistical package v.17 to describe the demographic characteristics of the sample. In the next step, producers' perceptions of the collective activities based on the identified factors were measured. Next, principal component analysis with varimax rotation was carried out in order to check the unidimensionality of the variables used to operationalize the dimensions of collective action evaluation criteria. All items with Eigen values above one were extracted. Eigen values measure the variances of the factors. In addition, all factors with factor loadings above 0.5 were retained. The loadings measure the contribution or relationship between the observed variables and the unobserved (latent) variables To test for the appropriateness of the factor analysis for the scale, The Kaiser-Meyer-Olkin Measure of Sampling Adequacy (KMO-MSA) was used and all fell within the accepted region of more than 0.5 (Nunnally, 1978). The measurement scale of the factors was validated by conducting a reliability test using the Cronbach Alpha. The results of the Pricipal Component Analysis (PCA) and the reliability test, shown in Table 3, indicated that all of the latent variables had an alpha value greater than the recommended 0.70 .

In the next stage of the statistical analysis, standardized factor scores based on the PCA were subjected to a two-stage cluster analysis. The goal of the cluster analysis is to establish groups that they are as internally homogenous as possible and that are externally heterogenous (Gyau et al., 2009). An important question was how many clusters were to be used especially against the background that by increasing the number of clusters, we reduce the dissimilarity within each cluster, but at the expense of a description of the data which has more degrees of freedom and is therefore less parsimonious (Gough \& Sazou, 2005).

Using the standard form of SPSS, we carried out a hierarchical cluster analysis. By examining the dendrogram from the hierachical cluster analysis, scree plots and plausibility considerations, a two cluster solution was 
identified as the optimal number of clusters. The number of clusters was then fed into the k-means cluster analysis to obtain the final cluster solution.

\section{Results}

\subsection{Description of the Sample}

Results of the statistical analysis indicate that less than $4 \%$ of the farmers are young (up to 30 years). About $24 \%$ of the respondents are aged over 61 years. About $19 \%$ of the respondents have no education and $54 \%$ have only primary education. Only $0.5 \%$ ( 1 person) have a university education. About $75 \%$ of the respondents are males and $25 \%$ are females. For the majority of the respondents $(81.3 \%)$ income from kola forms less than half of their income.

\subsection{Producers' Evaluation Criteria for Collective Action and Development of Constructs}

Results from the focus group discussions indicate that producers have both positive and negative views on the effectiveness of collective action interventions. Positive factors mentioned by producers include effectiveness of the interventions in reducing time used to look for buyers, in reducing transportation cost, in enabling them to learn and acquire new skills in production, harvesting and post harvest handling, and in enhancing their social status, improving social networks and improving market access and profitability.

Negative factors mentioned in the focus group discussions included loss of autonomy and confidence, delays and conflicts among members of the groups. The positive and negative factors were then synthesized and grouped into five main dimensions as shown in Table 2. These dimensions are transaction cost reduction, new learning and skill acquisition, market and financial improvements, social networks and status and unfavorable or negative factors. Each dimension was measured with three to six statements.

\subsection{Producers' Perception of the Collective Action}

The findings on producers' perceptions are reported below and are grouped according to the five dimensions discussed above.

\subsubsection{Reduced Transaction Cost}

The majority of the farmers interviewed have a positive perception about the ability of collective action to reduce transaction costs. For instance, $92 \%$ of the respondents agree or strongly agree that collective action has enabled them to reduce the time they used to look for buyers. Almost $90 \%$ are of the view that collective action has reduced the time they used to send the product to the market and $77.5 \%$ report a reduction in their transportation costs.

\subsubsection{New Learning and Skills Acquisition}

About $63 \%$ of the producers interviewed agreed or strongly agreed that their involvement in collective action has improved their skills in storage and conservation of kola. This percentage is lower than percentages reported to benefit from transaction cost reduction. One of the main reasons is that producers still complain that post harvest handling of kola as a major problem and seem not to be fully satisfied with the contribution of collective action in that respect. Kola in the study area can be infested with kola weevils and although collective action initiatives teach farmers how to reduce such losses, farmers find that the methods are often not effective. All in all, although many farmers perceive the collective action initiatives as helping to acquire skills, the proportion is low compared to the proportion positively evaluating its other benefits.

\subsubsection{Marketing and Financial Improvement}

Most of the respondents agreed or strongly agreed that collective action leads to improvement in their financial status. Approximately $82 \%$ agreed or strongly agreed that it has led to improvement in the quantity of kola nuts which they sell. About $85 \%$ felt that group activities have led to improvement in the prices for kola they receive. This therefore shows that organizations which are training farmers on how they can organize group sales are making gains as farmers seem to be benefitting from them and improving their overall economic wellbeing. This mainly occurred because where farmers are organized in groups, they are often able to take joint actions such as negotiating for better prices with traders than when they have to sell individually. Farmers also noted improvement in their knowledge about marketing.

\subsubsection{Improved Social Networks and Status}

The importance of group initiatives in improving farmers' social networks and status was also noted. Farmers were almost unanimous (97\%) that collective action has enabled them to come in contact with new people. The majority also mentioned that this was as an important consideration in their decision to join the kola group. 
According to them, it is not only the financial benefits which are important but also the social benefits, such as helping each other in times of crisis such as funerals or financial problems. This according to them is better served when one participates in a group and thus increases one's social networks.

More than $60 \%$ were of the view that the kola collective action group has led to improvement in their social status and enabled them to earn respect in their respective communities. Although, this is high, it is not as high as their support for the other statements as used in the other dimensions.

\subsubsection{Unfavorable Dimension of Collective Action}

The study also assessed farmers' perceptions of negative aspects of collective action. As high as $32 \%$ agreed or strongly agreed that collective action has led to a loss of autonomy during negotiations. This is the result of the fact that during group sales, individual farmers are not allowed to negotiate their prices on their own. The strategy used is that all participants put the products together and agree on a common price with the traders. Although most farmers agree that this has resulted in increased prices and price stability, they would have wished that their role in the price negotiations was more active than it is now.

Furthermore, about $44 \%$ of the respondents are of the view that collective action has added more to their work load. This is expected because through collective action, farmers are now trained and encouraged to do sorting and grading of their kola which was not done previously. This new development is seen as more work for the farmers.

\subsection{Classification of Producers Based on Perceptions}

In the next stage, farmers were classified according to their scores on the evaluation criteria. This was to identify and link the perceptual measures against farmers' characteristics. In order to do the classification, PCA was conducted on the dimensions of the collective action perceptions. These were then used as the clustering variables. This is further illustrated below:

\subsubsection{PCA of the Dimensions of Farmers' Evaluation Criteria}

The results of the PCA of the producers' evaluation criteria indicate that all of the variables used were uni-dimensional. However, some of the original statements used to operationalize the variables as shown in Table 2 were deleted for insufficient factor loading (less than 0.5). For instance, out of the four statements which were initially used to measure dimension, social networks and status, one was deleted in the PCA: the statement "Being a member of the group has helped me to be in contact with many people." It was deleted because it did not make adequate contribution to the latent variable. Also, three statements out of the initial six used to operationalize the unfavorable dimension of collective action were also deleted. The results of the PCA are shown in Table 3.

\subsubsection{Description of Clusters}

By using the dimensions of farmers' evaluation criteria and demographic characteristics, two main clusters were identified as illustrated in tables 3 and 4 . The clusters are described below:

Cluster 1 (Positive oriented group): Members in cluster 1 consist of $76 \%$ of the total respondents and as such is made up of majority of the respondents. Members in this group are more likely to continue with collective action since they generally have a very high positive perception of all the dimensions relating to the benefits of collective action. They believe that collective action reduces transaction cost, improves their marketing performance, provides social and financial benefits, and facilitates acquisition of required skills to effectively engage in collective action. Members of this cluster believe that collective action has few negative issues. Examination of the demographic characteristics of this group of farmers reveal that many are married and very few are separated indicating that the members in this group seem to have a more stable family relationships. More of members in this group also receive a relatively higher percentage of their incomes from kola nut compared to members in cluster 2 . Given their perception ratings of collective action, this group is referred to as "Positive-oriented group"

Cluster 2 (Unimpressed group): This group forms the minority (24\%). They are not likely to continue with the collective action since they did not agree with positive statements about collective action. Rather, they have a higher degree of agreement with the negative dimension of collective action. In terms of their demography, a lower percentage of them are married compared to those in cluster 1 . All of the members of this group have a very low reliance of kola income as it accounts for not more than $30 \%$ of their annual income. This group was referred to as the "unimpressed group" 


\section{Discussions and Implications}

From the above mentioned results it can be observed that farmers evaluate collective action in the context of 4 main benefits namely: its ability to reduce transaction costs, improve financial performance, enhance social networks and status, and improve skills. They also noted the negative dimensions of collective action, namely loss of negotiating autonomy and added work.

The variables identified in the focus group corroborate previous studies on collective action. For instance, in a review of how collective action impacts women's livelihoods, Pyburn et al., (2010) described nine benefits sought or gained by those who engage in collective action: (1) capacity building, (2) access to resources including knowledge and storage facilities, (3) access to finance, (4) reduced marketing cost (5) improved coordination, (6) increased bargaining power, (7) access to new markets, (8) building trust with other chain actors, and (9) building social capital including networks and social learning. The first, fourth, and ninth are identical to the benefits farmers involved in the reported study cited; the fourth benefit the farmers' cited, financial performance, can be viewed as incorporating Pyburn et al.'s fourth, sixth and seventh benefit. This therefore suggests that case specific context and issues and specificities of the industry being studied will determine the kinds of benefits which are expected by participants. For example, farmers involved in this study did not cite access to finance because they were not aware of opportunities to access finance through their groups.

All in all, producers exhibited a positive evaluation of the collective action initiatives as many agreed on the benefits that collective action can bring. Two groups of farmers obtained from the cluster analysis points to the fact that whilst the majority of the producers $(76 \%)$ have a positive perception of the collective action initiatives, a lesser percentage $(24 \%)$ view it negatively. Certainly, in the kola case, collective action initiatives can be perceived as an important strategy to link smallholders to markets as well as contribute to their financial and social development. The above findings corroborate the study by Poulton et al. (2005) who argued that smallholder farmers face very high transaction costs compared to large scale producers suggesting that transaction cost reduction can be important for increasing the benefits of small scale farmers from the marketing of their products. Markelova et al. (2009) also argue that collective initiative can reduce transportation costs and that innovations in marketing arrangements can transform marketing relations in favor of smallholder farmers.

Furthermore, the positive oriented group seems have a much more stable family status compared to the unimpressed minority. One possible explanation is that since married farmers generally have more responsibilities compared to their younger counterparts, they are more likely to have a positive evaluation of any development activity which promises to lessen the burden on their resources. This supports the view of Appiah et al. (2011) who in studying rabbit technology adoption in Ghana argued that married people are more likely to adopt the technology than unmarried people mainly because of their responsibilities and desire to make ends meet. Conversely, those who viewed collective action negatively are single farmers. A possible explanation is that the unmarried farmers are more mobile compared to their counterparts and therefore, are more able to look for other opportunities which might even fall outside their geographical region.

In addition, although women form the minority in both groups representing $24.6 \%$ of the entire population, women represent $22.9 \%$ and $15.5 \%$ respectively for the unimpressed and the positive oriented groups indicating that a higher proportion of women than men are dissatisfied with collective action. However, gender does not influence group membership. This implies that whether a farmer is satisfied or not with the group activities is not determined by gender. This contradicts the results of some studies which indicate that women are not able to participate in collective action because of domestic responsibilities and cultural attitudes which limit their participation in marketing cash crops such as kola. For instance, Donovan et al (2008) in reviewing rural collective enterprise development in developing countries, attributed women's low participation in rural enterprise development to cultural factors and women's domestic tasks. According to them, in most cases, women are not very prominent in the decision making process. This leads to lower evaluation of collective action by women compared to men. Pioneti et al. (2010) citing Develtere et al. (2008) also observed that women are underrepresented in and discriminated against in formal large producer organizations which limit memberships to head of households which are mainly men. Pioneti et al. (2010) identified many reasons for low women participation in collective initiatives including land tenure systems which are mainly patriarchal, socio-cultural roles of women which limit their participation in large commercial activities, and the time and social capital required to embark on collective action. However, the context of kola seems to be different because many of the activities involved in kola nut marketing such as washing, sorting and grading are done by women and therefore provide a high level of participation and involvement by women.Furthermore, since the 
unimpressed group of producers earn a low percentage of their income from kola, they are more likely to evaluate it negatively since kola might be relatively unimportant for them.

The findings have implication for the organization of future collective action activities. First, we argue that although the majority of the farmers view collective action positively, differentiated strategies have to be used in order to reach out and promote collective action among farmers who belong to the two groups. For example, whilst one of the objectives of the collective initiatives is to enhance farmers' skills in the area of marketing, conservation and value adding along the supply chain, this seems not to be achieved as satisfactorily compared to the other objectives. This therefore suggests the need to emphasize skill acquisition in the future implementation of collective action initiatives so as to enhance farmers' evaluation and benefits. In particular, they are yet to learn and obtain the needed skills which can help to store kola successfully in order to reduce post harvest losses. This aspect could be an area to be focused on by collective action promoters particularly because only $63 \%$ felt the initiatives enhance conservation techniques compared to other benefits which obtained a score of more than $80 \%$.

For the unimpressed group, it is not just the skill acquisition which they are unsatisfied with but also the lack of autonomy in negotiation and the time involved. The initiatives should therefore be strengthened in some of the other dimensions which will make them more attractive to the minority as well. For example, farmers could be allowed to determine price levels which they would like to sell their kola instead of current system which normally involves negotiations between representatives of farmer organizations and traders. This would ensure that farmers play a more active role in the price negotiation process. It is expected that this will not only influence the minority to join but will also further consolidate the gains made with the positive oriented group and increase overall participation.

\section{Conclusion and Future Research}

From the empirical findings, it can be concluded that kola producers in the western highlands of Cameroon have five main important criteria in evaluating the benefits of collective action. Farmers' perceptions elicited through the empirical studies show that in general, farmers have a positive perception of the collective action activities being organized to improve their skills and market access. Nevertheless, results of cluster analysis indicate that farmers are not homogenous in their perceptions. Two groups emerged from the analysis: one group which forms the majority has a positive perception whereas the minority group viewed it negatively. It is concluded that differentiated strategies have to be used in order to reach out to the two groups in promoting collective action as a way forward for market entry.

The present study has some limitations which have to be considered in interpreting the results and for future studies. Cross sectional data were used to measure farmers' perceptions. However, farmers' perception may change over time (Gyau et al., 2007) as they obtain more experience and get more information. Future research should therefore consider using time series data about these perceptions in order to capture trends over time. Second, the data involve farmers perceptions which may not be accurate, either because farmers are not being honest in interviews or because they may be incorrect in their perceptions about certain criteria, e.g., profitability. Whereas we have confidence in the methods we have used to ensure that farmers are being honest, future studies should collect data on objective factors, e.g, prices, quantities sold, and profitability to ensure that farmers perceptions of these are indeed accurate.

Finally, although we have identified the various dimensions which are valued by farmers in evaluating collective action, the present study did not consider their relative importance. Such information would be useful to promoters of collective action to help them to prioritize the factors whenever tradeoffs are necessary. It will therefore be important to investigate the relative importance of the various evaluation criteria which can be achieved through the use of choice modeling in future research.

\section{References}

Agrawal, A. (2001). Common property institutions and sustainable governance of resources. World Development, 29(10), 1649-1672. http://dx.doi.org/10.1016/S0305-750X(01)00063-8

Appiah, P., Nimo, F., Tham-agyekum, E. \& Tracoh, L. (2011). Rabbit technologies: adoption studies in the Ashanti region of Ghana. African Journal of Agricultural Research, 6(11), 2539-2543.

Baland, J. \& Platteau, J. (1996). Halting degradation of natural resources: is there a role for rural communities? FAO/Claredom Press/Oxford University Press. New York/Oxford/New York

Barham J. \& Chitemi C. (2009). Collective action to improve marketing performance: Lessons from farmer groups in Tanzania. Food Policy, 34, 53-59. http://dx.doi.org/10.1016/j.foodpol.2008.10.002 
Coulter, J. (2007). Farmer groups enterprises and the marketing of staple foods in Africa. CAPRi Working Paper, 72 .

Devaux, A., Horton, D. Velasco, C. Thiele, G., Lopez, G., Barnet, T. Reinoso, I. \& Ordinola, M. (2009). Collective action for market chain innovation in Andes. Food Policy, 34, 31-38. http://dx.doi.org/10.1016/j.foodpol.2008.10.007

Develtere, P, Pollet, I \& Wanyama, F.O. (2008). Cooperating out of poverty: the renaissance of the African Cooperative Movement, ILO, Geneva.

Donovan, J., Stoian, D. \& Poole, N. (2008). Global review of rural community enterprise: the long and winding road to creating viable businesses, and potential shortcuts. The Tropical Agricultural Research and Higher Education Centre (CATIE) Technical Bulletin nr 29.

Dorward, A. Kydd, J., Morrison, J., \& Urey, I. (2003). A policy agenda for pro poor agricultural growth. World Development, 32 (1), 73-89. http://dx.doi.org/10.1016/j.worlddev.2003.06.012

Facheux, C., Gyau' A.,Diane, R., Foundjem-Tita, D., Mbosso C., Franzel, S. \& Tchoundjeu Z. (2010). Comparison of three modes of improving benefits to farmers within agroforestry product market chains in Cameroon. Development Policy Review (In review).

Food \& Agriculture Organisation (FAO). (2010). Producer organizations: reclaiming opportunities for development. Policy brief prepared by FAO regional office in Africa.

Gough, O. \& P.D. Sozou. (2005). Pensions and retirement savings: cluster analysis of consumer behaviour and attitudes. International Journal of Bank Marketing, 23 (7), 558-570. http://dx.doi.org/10.1108/02652320510629917

Gyau, A. \& Spiller, A. (2007). The role of organizational culture in modelling buyer-seller relationships in the fresh fruit and vegetable trade between Ghana and Europe. African Journal of Business Management, 1 (8), 218-229.

Gyau, A., Voss, J., Spiller, A. \& Enneking, U. (2009). Farmer acceptance of GM-seeds in Germany: results of a cluster analysis. International Food and Agribusiness Management Review, 12(4), 61-80.

Humphrey, J. (2005). Shaping value chains for development: Global value chains in agricultural business. Eschborn Germany. GTZ.

Kariuki, G. \& Place, F. (2005). Initiatives for rural development through collective action: the case of household participation in group activities in the highlands of Central Kenya, CAPRi working papers 43, International Food Policy Research Institute (IFPRI).

Kruijssen, F. \& Giuliani. A. (2006). Collective action for small scale producers of agricultural biodiversity products. Research Workshop on Collective Action and Market Access for Smallholders. October 2-5 call. Columbia.

Markelova, H., Meinzen-Dick, R. Hellin, J. \& Dohrn, S. (2009). Collective action for smallholder market access. Food policy, 34(1), 1-7. http://dx.doi.org/10.1016/j.foodpol.2008.10.001

Neba, A. (1999). Modern Geography of the Republic of Cameroon, 3rd ed. Bamenda: Neba Publishers.

Nunnally, J.C. (1978). Psychometric Theory (2nd Edition ed.), McGraw-Hill, New York.

Ostrom, E. (1990). Governing the commons: evolution of institution for collective action. Cambridge University Press, Cambridge.

Ostrom, E. (1992). The rudiments of the theory of the origins, survival and performance of common property institutions. In: Bromly W. (ed). Making the commons work: Theory, practice and politics. ICS press, San Francisco, CA.

Pioneti, C., Adenew, B., \& Abadi, Z. (2011). Characteristics for women collective action for enabling women's participation in agricultural markets: preliminary findings from Ethiopia. Paper presented at ILRI Gender and agriculture. 31st January to 2nd February 2011, Addis Ababa, Ethiopia.

Poulton, C., Doward, A. \& Kydd, J. (2005). The future of small farms: new direction for services, institutions and intermediation. Paper presented at the future of small farms workshop, 26-29 June 2005. Imperial College, Wye, UK.

Shepherd, A. (2007). Approaches to linking producers to markets. Agricultural management, marketing and finance. Food and agriculture Organisations of the United Nations, Rome, Italy, (Occassional paper, 13). 
Vermillion, D. (2001). Property rights and collective action in the devolution of irrigation system management. In Meinzen-Dick, R., A. Knox, M. Di Gregorio ed. Collective action, property rights and devolution of natural resource management: Exchange of knowledge and implications for policy. Feldafing, Germany: Zentralstelle fur Ernaehrung und Landwirtschaft (ZEL), Food and Agriculture Development Centre.

Wade, R. (1988). Village republic: economic condition for collective action in south India. ICS press. San Francisco, CA

Table 1. Description of the sample

\begin{tabular}{|l|c|c|}
\hline Variable & number & Percentage (\%) \\
\hline Age of respondents & & \\
\hline Up to 30 & 9 & 4.4 \\
\hline $31-50$ & 107 & 52.7 \\
\hline $51-60$ & 38 & 18.7 \\
\hline 61 and above & 49 & 24.1 \\
\hline Sex of respondents & & \\
\hline Male & 153 & 75.4 \\
\hline Female & 50 & 24.6 \\
\hline Level of education & & \\
\hline No schooling & 39 & 19.2 \\
\hline Primary & 109 & 53.7 \\
\hline Secondary & 54 & 26.7 \\
\hline Tertiary & 1 & 0.5 \\
\hline Proportion of income from Kola & & \\
\hline Up to $50 \%$ of income & 165 & 81.3 \\
\hline Greater than $50 \%$ & 38 & 18.7 \\
\hline Proportion of income & & \\
\hline Up to 30\% & 132 & 65 \\
\hline $31-60 \%$ & 43 & 21.2 \\
\hline Over 60\% & 28 & 18.8 \\
\hline & & \\
\hline
\end{tabular}


Table 2. Producers' perception of collective action

\begin{tabular}{|c|c|c|c|c|c|}
\hline Statement & $\begin{array}{l}\text { Strongly } \\
\text { Disagree } \\
(\%)\end{array}$ & $\begin{array}{l}\text { Disagree } \\
(\%)\end{array}$ & $\begin{array}{l}\text { Agree/ } \\
\text { disagree } \\
(\%)\end{array}$ & $\begin{array}{l}\text { Agree } \\
(\%)\end{array}$ & $\begin{array}{l}\text { Strongly } \\
\text { agree }(\%)\end{array}$ \\
\hline & \multicolumn{5}{|c|}{ (Numbers of respondents with percentages in brackets) } \\
\hline \multicolumn{6}{|l|}{ Transaction costs } \\
\hline ... reduced the time I used to look for buyers & $1(0.5)$ & $6(3.0)$ & $10(4.9)$ & $121(59.6)$ & $65(32)$ \\
\hline $\begin{array}{l}\text {... reduced the time I used to take the products to } \\
\text { the market }\end{array}$ & 0 & $5(2.5)$ & $16(7.9)$ & $117(57.6)$ & $65(32)$ \\
\hline ... reduced transportation cost considerably & 0 & $4(2.6)$ & $30(19.9)$ & $79(52.3)$ & $38(25.2)$ \\
\hline \multicolumn{6}{|l|}{ New learning and skills acquisitions } \\
\hline $\begin{array}{l}\text {.. improved my skills in storage techniques and the } \\
\text { quality of the products }\end{array}$ & $15(7.6)$ & $26(13.1)$ & $31(15.7)$ & $87(43.9)$ & $39(19.7)$ \\
\hline ... improved my skills in kola harvesting techniques & $11(6)$ & $22(12)$ & $30(16.3)$ & $89(48.4)$ & $32(17.4)$ \\
\hline ... improved skills in kola conservation techniques & $14(7.1)$ & $28(14.3)$ & $31(15.8)$ & $94(48.0)$ & $29(14.8)$ \\
\hline \multicolumn{6}{|l|}{ Market and financial improvement } \\
\hline ... increased the quantity of kola nut I sell & $3(1.5)$ & $15(7.4)$ & $39(19.3)$ & $79(39.1)$ & $66(32.7)$ \\
\hline ... increased my knowledge in marketing & 0 & $5(2.5)$ & $15(7.4)$ & $132(65.3)$ & $50(24.8)$ \\
\hline ... obtained better price for my products & $2(1)$ & $3(1.5)$ & $22(11)$ & $104(52)$ & $69(34.5)$ \\
\hline ... entered in contact with new buyers & $7(3.5)$ & $4(2.0)$ & $20(10.1)$ & $107(54)$ & $60(30.3)$ \\
\hline ... more stable prices for my products & $2(1)$ & $2(1)$ & $22(11)$ & $136(68)$ & $38(19)$ \\
\hline ... improved on kola quality related information & $2(1)$ & $6(3)$ & $32(15.9)$ & $122(60.7)$ & $39(19.4)$ \\
\hline \multicolumn{6}{|l|}{ Social networks and status } \\
\hline $\begin{array}{l}\text { Being a member of the group enables me to earn } \\
\text { respect in my community }\end{array}$ & $2(1.0)$ & $4(2.0)$ & $66(32.5)$ & $95(46.8)$ & $36(17.7)$ \\
\hline $\begin{array}{l}\text { Being a member of the group improves my social } \\
\text { status in the community }\end{array}$ & $2(1)$ & $4(2)$ & $69(34)$ & $94(46.3)$ & $34(16.7)$ \\
\hline $\begin{array}{l}\text { My reputation as kola nut farmer improves by } \\
\text { becoming a member of the group }\end{array}$ & 0 & $4(2)$ & $53(26.1)$ & $107(52.7)$ & $39(19.2)$ \\
\hline $\begin{array}{l}\text { Being a member of the group has helped me to be } \\
\text { in contact with many people }\end{array}$ & 0 & 0 & $7(3.4)$ & $110(54.2)$ & $86(42.4)$ \\
\hline \multicolumn{6}{|l|}{ Negative perceptions } \\
\hline ... noticed more conflicts among group members & $109(54.0)$ & $51(25.2)$ & $27(13.4)$ & $10(5.0)$ & $5(2.5)$ \\
\hline$\ldots$ lost autonomy to negotiate on my own & $36(18.0)$ & $46(23.0)$ & $52(26.0)$ & $34(17.0)$ & $32(16.0)$ \\
\hline $\begin{array}{l}\text {... noticed that some executive members are not } \\
\text { transparent }\end{array}$ & $87(43.3)$ & $60(29.9)$ & $31(15.4)$ & $13(6.5)$ & $10(5.0)$ \\
\hline $\begin{array}{l}\text {.. encountered some delays in the selling of the } \\
\text { products }\end{array}$ & $52(25.9)$ & $66(32.8)$ & $51(25.4)$ & $29(14.4)$ & $3(1.5)$ \\
\hline $\begin{array}{l}\ldots \text { added more work to the business because of } \\
\text { sorting and grading }\end{array}$ & $36(17.7)$ & $20(9.85)$ & $56(27.58)$ & $80(39.41)$ & $10(4.93)$ \\
\hline $\begin{array}{l}\text {.. lost the confidence I used to have with my } \\
\text { regular buyers }\end{array}$ & $45(22.4)$ & $56(27.9)$ & $47(23.4)$ & $43(21.4)$ & $10(5.0)$ \\
\hline
\end{tabular}


Table 3. Factor analysis of perception variables

\begin{tabular}{|c|c|c|}
\hline Factors and Items & Factor Loadings & $\begin{array}{l}\text { Mean } \\
\text { (s.d.) }\end{array}$ \\
\hline \multicolumn{3}{|l|}{$\begin{array}{l}\text { Transaction cost } \\
\text { KMO }=.686, \text { Cronbach's alpha }=.905, \text { Explained variance }=84.12 \%\end{array}$} \\
\hline$\ldots$ reduced the time I used to take the products to the market & 0.956 & $\begin{array}{l}4.19 \\
(0680)\end{array}$ \\
\hline ... reduced the time I used to look for buyers & 0.911 & $\begin{array}{l}4.20 \\
(.704)\end{array}$ \\
\hline ... reduced transportation cost considerably & 0.833 & $\begin{array}{l}4.00 \\
(.748)\end{array}$ \\
\hline \multicolumn{3}{|l|}{$\begin{array}{l}\text { New learning and skills } \\
\text { KMO }=.744, \text { Cronbach's alpha }=.880, \text { Explained variance }=80.68 \%\end{array}$} \\
\hline ... improved skills in kola conservation techniques & 0.906 & \\
\hline ... improved my skills in storage techniques and the quality of the products & 0.899 & $\begin{array}{l}3.55 \\
(1.169) \\
\end{array}$ \\
\hline ... improved my skills in kola harvesting techniques & 0.890 & $\begin{array}{l}3.59 \\
(1.093) \\
\end{array}$ \\
\hline \multicolumn{3}{|l|}{$\begin{array}{l}\text { Market and financial improvement } \\
\text { KMO }=.886, \text { Cronbach's alpha }=.893, \text { Explained variance }=65.67 \%\end{array}$} \\
\hline$\ldots$ more stable prices for my products & 0.879 & $\begin{array}{l}4.03 \\
(.657)\end{array}$ \\
\hline ... obtained better price for my products & 0.862 & $\begin{array}{l}4.18 \\
(0.760)\end{array}$ \\
\hline . increased my knowledge in marketing & 0.857 & $\begin{array}{l}4.12 \\
(.638)\end{array}$ \\
\hline ... increased the quantity of kola nut I sell & 0.809 & $\begin{array}{l}3.94 \\
(.976)\end{array}$ \\
\hline ... improved on Kola quality related information & 0.802 & $\begin{array}{l}3.95 \\
(.750)\end{array}$ \\
\hline ... entered in contact with new buyers & 0.627 & $\begin{array}{l}4.06 \\
(.897)\end{array}$ \\
\hline \multicolumn{3}{|l|}{$\begin{array}{l}\text { Social networks and status } \\
\text { KMO }=.741, \text { Cronbach's alpha }=.903, \text { Explained variance }=\mathbf{6 6 . 8 3 \%}\end{array}$} \\
\hline Being a member of the group enables me to earn respect in my community & 0.919 & $\begin{array}{l}3.78 \\
(.791)\end{array}$ \\
\hline Being a member of the group improves my social status in the community & 0.912 & $\begin{array}{l}3.76 \\
(.787) \\
\end{array}$ \\
\hline My reputation as kola nut farmer improves by becoming a member of the group & 0.872 & $\begin{array}{l}3.89 \\
(.723) \\
\end{array}$ \\
\hline \multicolumn{3}{|l|}{$\begin{array}{l}\text { Negative perceptions } \\
\text { KMO }=0.500 ., \text { Cronbach's alpha }=.621, \text { Explained variance }=57.58 \%\end{array}$} \\
\hline ... lost the confidence I used to have with my regular buyers & 0.886 & $\begin{array}{l}2.59 \\
(1.193)\end{array}$ \\
\hline lost autonomy to negotiate on my own & 0.711 & $\begin{array}{l}2.90 \\
(1.326) \\
\end{array}$ \\
\hline$\ldots$ added more work to the business because of sorting and grading & 0.661 & $\begin{array}{l}3.04 \\
(1.188)\end{array}$ \\
\hline
\end{tabular}


Table 4. Producer's perception of collective action according group membership

\begin{tabular}{|c|c|c|c|}
\hline \multirow[t]{2}{*}{ Relationship variables } & $\begin{array}{l}\text { Positive looking group } \\
\mathrm{n}=155 \\
(76.4 \%)\end{array}$ & $\begin{array}{l}\text { Unimpressed group } \\
n=48 \\
(23.6 \%)\end{array}$ & $\begin{array}{l}\text { t-stat } \\
\text { sig }\end{array}$ \\
\hline & $\mu$ & $\mu$ & \\
\hline Transaction costs & 0.17 & -1.99 & $* * *$ \\
\hline Market and financial improvement & 0.14 & -2.03 & $* * *$ \\
\hline Skills acquisition & 0.08 & -1.22 & $* * *$ \\
\hline Social dimension & 0.08 & -1.36 & $* * *$ \\
\hline Negative dimensions & 0.14 & -0.40 & $* * *$ \\
\hline
\end{tabular}

$* * *=$ significant at $1 \%$

Table 5. Comparison of the producers groups according to demographic characteristics

\begin{tabular}{|c|c|c|c|c|c|}
\hline \multirow{2}{*}{$\begin{array}{l}\text { Variable } \\
\text { Age (years) }\end{array}$} & \multicolumn{2}{|c|}{$\begin{array}{l}\text { Positive oriented group } \\
\mathrm{N}=155\end{array}$} & \multicolumn{2}{|c|}{$\begin{array}{l}\text { Unimpressed group (\%) } \\
\mathrm{N}=48\end{array}$} & \multirow[t]{2}{*}{$\begin{array}{l}\text { F stat } \\
\text { sig }\end{array}$} \\
\hline & Number & $\%$ & Number & $\%$ & \\
\hline Up to 30 & 4 & 2.6 & 3 & 6.3 & ns \\
\hline $31-50$ & 80 & 51.6 & 30 & 62.5 & ns \\
\hline $51-60$ & 27 & 17.4 & 13 & 27.1 & ns \\
\hline $61+$ & 44 & 28.4 & 2 & 4.2 & ns \\
\hline \multicolumn{6}{|l|}{ Education } \\
\hline No education & 28 & 18.1 & 11 & 22.9 & ns \\
\hline Primary & 73 & 47.1 & 20 & 41.7 & ns \\
\hline Secondary and high school & 53 & 34.2 & 17 & 35.4 & ns \\
\hline Tertiary & 1 & 0.6 & 0 & 0 & ns \\
\hline \multicolumn{6}{|l|}{ Sex } \\
\hline Male & 131 & 84.5 & 37 & 77.1 & ns \\
\hline Female & 24 & 15.5 & 11 & 22.9 & ns \\
\hline \multicolumn{6}{|l|}{ Marital status } \\
\hline Married & 143 & 92.3 & 32 & 66.7 & $* *$ \\
\hline Single and never married & 7 & 4.5 & 4 & 8.3 & $* *$ \\
\hline Separated & 4 & 2.6 & 6 & 12.5 & $* *$ \\
\hline Widow(er) & 1 & $0.6 \%$ & 6 & 12.5 & $* *$ \\
\hline \multicolumn{6}{|l|}{ Proportion of income } \\
\hline Up to $30 \%$ & 114 & 73.5 & 48 & 100 & $* *$ \\
\hline $31-60 \%$ & 29 & 18.7 & 0 & 0 & $* *$ \\
\hline Over $60 \%$ & 12 & 7.7 & 0 & 0 & $* *$ \\
\hline
\end{tabular}

$* *=$ significant at $5 \%, \mathrm{~ns}=$ not statistically significant 